\title{
PENGEMBANGAN E-LKPD BERBASIS DISCOVERY LEARNING MENGGUNAKAN APLIKASI ADOBE ACROBAT 11 PRO EXTENDED PADA MATERI KESETIMBANGAN ION DAN PH LARUTAN GARAM UNTUK KELAS XI SMA/MA SEDERAJAT
}

\author{
Aulia Agustha ${ }^{1}$, Susilawati ${ }^{2}$, Sri Haryati ${ }^{3}$ \\ ${ }^{123}$ Pendidikan Kimia, Universitas Riau \\ *Email: auliaagustha412@gmail.com
}

\begin{abstract}
Abstrak
Penelitian ini bertujuan untuk mengembangkan E-LKPD berbasis Discovery Learning menggunakan aplikasi Adobe Acrobat 11 Pro Extended pada materi kesetimbangan ion dan $\mathrm{pH}$ larutan garam untuk kelas XI SMA/MA, mengetahui kevalidan E-LKPD berdasarkan aspek kelayakan isi, karakteristik Discovery Learning, aspek kebahasaan, aspek penyajian, aspek kegrafisan, ukuran, desain sampul, desain isi dan mengetahui respon pengguna terhadap E-LKPD yang dikembangkan. Penelitian pengembangan ini merupakan jenis Research and Development $(R \& D)$ dengan model pengembangan Plomp. Adapun instrumen pengumpulan data berupa lembar validasi yang diberikan kepada dua validator materi dan dua validator media, serta angket respon pengguna untuk guru dan peserta didik. Setelah dilakukan revisi sebanyak dua kali diperoleh hasil validitas oleh validator materi pada aspek kelayakan isi sebesar 94,44\%, aspek karakteristik Discovery Learning sebesar 95,83\%, aspek penyajian sebesar $90 \%$, aspek kebahasaan sebesar $90,62 \%$ dan aspek kegrafisan sebesar 93,5\% yang masing-masing aspek tersebut termasuk dalam krtieria valid. Selanjutnya, hasil analisis data diperoleh validitas oleh validator media pada aspek kegrafisan yang meliputi ukuran E-LKPD sebesar $100 \%$, desain sampul sampul sebesar 90,63\%, dan desain isi sebesar 94,32\% yang masing-masing aspek termasuk kategori valid. ELKPD yang telah dinyatakan valid oleh validator dilakukan uji satu-satu kepada 3 orang peserta didik yang sudah mempelajari kesetimbangan ion dan $\mathrm{pH}$ larutan garam. Selanjutnya meminta angket respon kepada 3 orang guru kimia dan 20 orang peserta didik. Hasil respon guru diperoleh sebesar 95,55\% termasuk kriteria sangat tinggi dan praktis, hasil respon peserta didik sebesar 90,75\% termasuk kriteria menarik. Berdasarkan hasil analisis data dapat disimpulkan bahwa E-LKPD berbasis Discovery Learning menggunakan aplikasi Adobe Acrobat 11 Pro Extended yang dihasilkan dinyatakan valid dan dapat digunakan pada mata pelajaran kimia SMA pada materi kesetimbangan ion dan $\mathrm{pH}$ larutan garam.
\end{abstract}

Kata kunci : Kesetimbangan Ion dan pH Larutan Garam, Discovery Learning, E-LKPD, Adobe Acrobat 11 Pro Extended

Abstract

This study aims to develop E-LKPD based on Discovery Learning using the Adobe Acrobat 11 Pro Extended application on the ion balance and $\mathrm{pH}$ of salt solution for class XI SMA / MA, to determine the validity of E-LKPD based on aspects of content feasibility, characteristics of Discovery Learning, linguistic aspects, presentation aspects, graphic aspects, size, cover design, content design and knowing the user's response to the developed E-LKPD. This development research is a type of Research and Development (R\&D) with the Plomp development model. The data collection instruments are in the form of validation sheets given to two material validators and two media validators, as well as user response questionnaires for teachers and students. After two revisions, the validity results obtained by the material validator on the content feasibility aspect were $94.44 \%$, the characteristic aspects of Discovery Learning were $95.83 \%$, the presentation aspects were 90\%, the linguistic aspects were $90.62 \%$ and the graphic aspects were $93.5 \%$ which each of these aspects is included in the valid criteria. Furthermore, the results of data analysis obtained validity by the media validator on the graphic aspect which included the E-LKPD size of $100 \%$, the cover design was $90.63 \%$, and the content design was $94.32 \%$, each of which was categorized as valid. E-LKPD which has been declared valid by the validator is tested one by one on 3 students who have studied the ion balance and $\mathrm{pH}$ of the salt solution. Then ask for a response 
questionnaire to 3 chemistry teachers and 20 students. The results of the teacher's response were $95.55 \%$ including very high and practical criteria, the results of students' responses were $90.75 \%$ including interesting criteria. Based on the results of data analysis, it can be concluded that the E-LKPD based on Discovery Learning using the Adobe Acrobat 11 Pro Extended application produced was validated and can be used in high school chemistry subjects on ion balance and $\mathrm{pH}$ of salt solution.

Keywords : Ion Balance and pH of Salt Solution, Discovery Learning, E-LKPD, Adobe Acrobat 11 Pro Extended

\section{Pendahuluan}

Pembelajaran merupakan suatu perubahan perilaku yang relatif tetap dan hasil praktik yang diulang-ulang. Subjek didalam pembelajaran adalah peserta didik yang menjadi pusat dari kegiatan belajar (M. Thobroni, 2015). Pembelajaran pada abad 21 mendorong peserta didik untuk memiliki keterampilan inti dan keterampilan khusus yaitu pemanfaatan teknologi informasi dan komunikasi (TIK) sehingga pendidik diharapkan dapat menggunakan media maupun bahan ajar yang mampu melibatkan peserta didik secara aktif, menyenangkan, menarik, dan interaktif (Trilling dan Fadel, 2009).

Hasil wawancara dengan guru kimia MAN 3 Pekanbaru dan SMAN 4 Pekanbaru diperoleh bahwa guru sudah menggunaan LKPD pada materi kesetimbangan ion dan $\mathrm{pH}$ larutan garam dalam proses pembelajaran, namun LKPD yang ada disekolah masih dalam bentuk cetak dan penyajian LKPD belum mampu membuat peserta didik terlibat dalam proses pembelajaran, dan juga perseta didik belum mampu menemukan konsep kimia secara mandiri serta menunjang kemampuan pemecahan masalah sehingga menyebabkan kurangnya kebermaknaan peserta didik dalam belajar.

Solusi untuk mengatasi permasalahan tersebut adalah diperlukan suatu LKPD yang terintegrasi kurikulum 2013 dan dapat menuntun peserta didik aktif dalam proses pembelajaran serta mengutamakan aktivitas peserta didik sehingga pembelajaran berpusat kepada peserta didik. Salah satu solusi yang dapat dilakukan adalah pengembangan LKPD berbasis Discovery Learning. Dengan LKPD berbasis Discovery Learning pendidik dapat mengarahkan pola pikir peserta didik, dapat menciptakan kemandirian peserta didik, dapat menemukan pengetahuan serta dapat mengaktifkan peserta didik dalam kegiatan pembelajaran. LKPD menggunakan model Discovery Learning ini juga dapat membuat peserta didik mencari sendiri pemecahan pada stimulasi yang diberikan serta dapat berperan aktif dalam mengidentifikasi masalah, 
mengumpulkan data, mengolah data, pembuktian, dan mengambil kesimpulan sebagai jawaban dari pemecahan masalah (Fitri Apriani Pratiwi, 2014).

Seiring dengan pandemic COVID-19 ini, seluruh aktivitas manusia dibatasi, termasuk kegiatan pembelajaran di sekolah. Sekolah mulai menerapkan kegiatan belajar berbasis digital guna membatasi penyebaran virus COVID-19 ini. Selama wawancara dengan guru kimia selama masa pandemic ini guru tidak menggunakan LKPD karena kurang efektif dalam proses pembelajaran online. Oleh karena itu, diperlukan suatu LKPD yang dapat digunakan dalam proses pembelajaran dengan menjadi LKPD kedalam bentuk elektronik.

E-LKPD yang telah dikembangkan berbentuk software yang dapat diakses melalui $P C$, android, USB, flashdrive dan sebagainya. Pada penelitian ini aplikasi yang digunakan untuk pembuatan E-LKPD ialah Adobe Acrobat 11 Pro Extended. Kelebihan dari aplikasi Adobe Acrobat 11 Pro Extended yaitu dapat menyajikan teks dan gambar, menghadirkan teknologi multimedia ke dalam selembar dokumen PDF, dan juga dapat menyajikannya ke dalam bentuk video, audio dan animasi flash (Efisitek, 2007).

LKPD berbasis Discovery Learning versi elektronik ini salah satunya dapat dikembangkan dengan aplikasi Adobe Acrobat 11 Pro Extended. E-LKPD dengan program Adobe Acrobat 11 Pro Extended dipilih peneliti dikarenakan beberapa alasan yaitu LKPD elektronik dapat digunakan sebagai salah satu bahan ajar yang dapat diakses mandiri, E-LKPD ini disesuaikan berdasarkan analisis kebutuhan, dan tingkat kemudahan pada penerapannya.

Penelitian Tika Eka Ningrum (2018) dengan judul Pengembangan Bahan Ajar Electronic Book menggunakan Software Adobe Acrobat 11 Pro Extended untuk SMK Kompetensi Keahlian Teknik Komputer dan Jaringan kelas $\mathrm{X}$, validasi hasil penilaian ahli media mendapat rata-rata skor 4,45 dengan persentase $89 \%$ (sangat baik) sedangkan hasil penilaian guru adalah 4,375 dengan persentase $87,5 \%$ (sangat baik) dan hasil penilaian peserta didik adalah 3,88 dengan persentase $77,6 \%$ (baik).

Penelitian dengan menggunakan bahan ajar elektronik pmerupakan salah satu inovasi baru bagi peserta didik dalam memahami materi pelajaran pada pembelajaran daring di sekolah. Dengan adanya penelitian ini peserta didik dapat menjawab secara langsung pada aplikasi yang disediakan, sehingga lebih mudah digunakan oleh 
peserta didik dan terdapat video pembelajaran yang dapat membantu peserta didik lebih memahami materi pelajaran. Berdasarkan pemaparan tersebut, maka peneliti tertarik untuk melakukan penelitian pengembangan bahan ajar berupa "Pengembangan E-LKPD Berbasis Discovery Learning Menggunakan Aplikasi Adobe Acrobat 11 Pro Extended pada Materi Kesetimbangan Ion dan pH Larutan Garam Untuk Kelas XI SMA/MA Sederajat

\section{Metode}

Penelitian telah dilaksanakan di Program Studi Pendidikan Kimia FKIP Universitas Riau dengan uji satu-satu di MAN 3 Pekanbaru, serta respon peserta didik di MAN 3 Pekanbaru dan SMAN 4 Pekanbaru. Model yang digunakan yaitu model pengembangan Plomp yang terdiri dari 5 tahapan yaitu, fase investigasi awal (preliminary investigation), fase desain (design), fase realisasi/konstruksi (realization/construction), fase validasi, revisi dan uji coba (evaluation, revision and test), dan fase implementasi (implementation). Namun penelitian ini dibatasi hanya pada fase validasi, revisi, dan uji coba karena tujuan dari penelitian ini untuk mengembangkan produk dan mengetahui respon pengguna. Desain penelitian pengembangan model Plomp dapat dilihat pada Gambar 1.

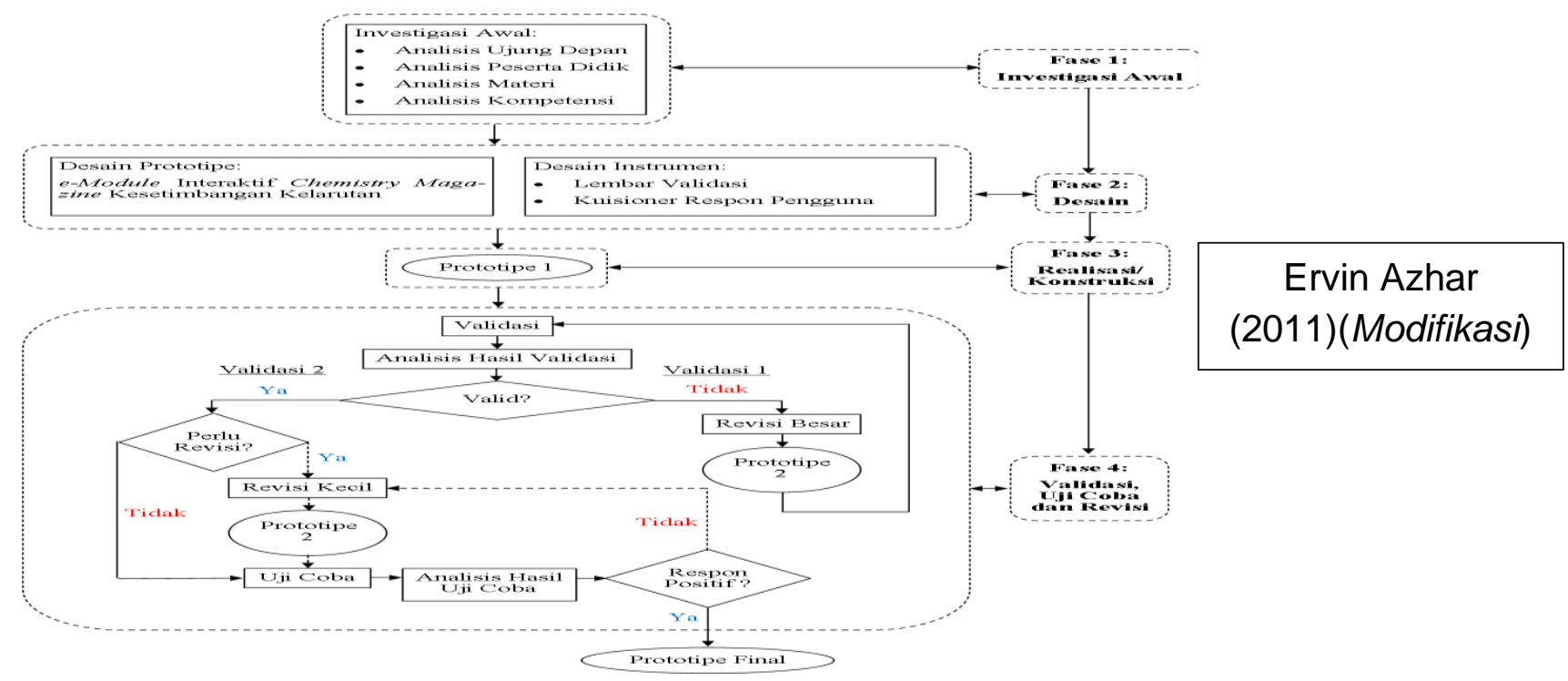

Gambar 1. Alur Pengembangan E-LKPD Berbasis Discovery Learning Menggunakan Aplikasi Adobe Acrobat XI Pro Extended Kesetimbangan Ion dan pH Larutan Garam dengan Model Plomp (Modifikasi) 


\section{Teknik Analisa Data}

Insturmen pengumpulan data yang digunakan dalam penelitian Pengembangan E-LKPD Berbasis Discovery Learning Menggunakan Aplikasi Adobe Acrobat XI Pro Extended Kesetimbangan Ion dan $\mathrm{pH}$ Larutan Garam adalah analisis validitas dan respon pengguna. Pengumpulan data diperoleh pada tahap pengembangan diantaranya sebagai berikut :

1. Validasi

2. Revisi

3. Penyebaran angket respon pengguna terhadap E-LKPD yang telah dikembangkan.

Adapun istrumen penelitian berupa :

1. Lembar validasi oleh 4 orang validator.

2. Uji satu-satu kepada 3 orang peserta didik yang telah mempelajari materi kesetimbangan ion dan $\mathrm{pH}$ larutan garam

3. Angket respon pegguna, terdiri dari 3 orang guru kimia dan 20 orang peserta didik yang sudah mempelajari materi kesetimbangan ion dan $\mathrm{pH}$ larutan garam.

Data yang telah dikumpulkan kemudian dianalisis dengan teknik analisis tertentu. Adapun rumus perhitungan yang digunakan dalam menentukan kategori rata-rata dari setiap aspek pada dlembar validasi sebagai berikut :

$$
P=\frac{\Sigma X}{\Sigma X i} \times 100 \%
$$

$$
\begin{aligned}
& \text { Keterangan : } \\
& \begin{aligned}
\mathrm{P} & =\text { Persentase skor }(\%) \\
\Sigma x & =\text { Jumlah nilai jawaban responden dalam satu item } \\
\Sigma \mathrm{xi} & =\text { Jumlah skor ideal dalam satu item }
\end{aligned}
\end{aligned}
$$

(Arikunto, 2006) 
Persentase yang diperoleh kemudian dikonversi menjadi nilai kualitatif dengan kriteria tertentu. Persentase skor digunakan untuk menguji tingkat kelayakan produk hasil penelitian pengembangan. Jika persentase skor hasil analisis data semakin besar maka tingkat kelayakan produk hasil penelitian pengembangan semakin baik. Kriteria dalam mengambil keputusan dalam validasi E-LKPD dapat dilihat pada Tabel 1.

Tabel 1. Persentase Tingkat Kevalidan Produk

\begin{tabular}{cc}
\hline Persentase & Keterangan \\
\hline $80,00-100$ & Baik/Valid/Layak \\
$60,00-79,99$ & $\begin{array}{c}\text { Cukup Baik/Cukup Valid/Cukup Layak } \\
\text { Kurang Baik/Kurang Valid/Kurang } \\
50,00-59,99\end{array}$ \\
$0-49,99$ & Layak \\
& Tidak Baik (Diganti) \\
\hline
\end{tabular}

(Riduwan. 2012)

Analisis respon pengguna menggunakan skala empat pilihan Likert dengan pedoman penskoran pada Tabel 2.

Tabel 2. Pedoman Penskoran Respon Pengguna

\begin{tabular}{cc}
\hline $\begin{array}{c}\text { Skala } \\
\text { Penilaian }\end{array}$ & Keterangan \\
\hline 4 & SS : Sangat Setuju \\
3 & S : Setuju \\
2 & KS : Kurang Setuju \\
1 & TS : Tidak Setuju \\
\hline
\end{tabular}

(Sugiyono, 2017).

Persentase yang diperoleh kemudian dirubah menjadi nilai kualitatif dengan kriteria validitas pada Tabel 3 .

Tabel 3. Kriteria Angket Respon Guru

Rata-Rata Skor(\%) Kriteria Respon Pengguna




$\begin{array}{cc}81,25<R \leq 100 & \text { Sangat Positif/Sangat baik } \\ 62,5<R \leq 81,25 & \text { Positif/Baik } \\ 43,75<R \leq 62,5 & \text { Kurang Positif/Kurang baik } \\ 25<R \leq 43,75 & \text { Tidak Positif/Tidak Baik }\end{array}$

(Valentina, 2015)

Tabel 4. Kriteria Respon Peserta Didik

\begin{tabular}{cc}
\hline Persentase & Kualifikasi \\
\hline $80 \%-100 \%$ & Menarik \\
$60 \%-79 \%$ & Cukup menarik \\
$50 \%-59 \%$ & Kurang menarik \\
$<49 \%$ & Tidak menarik \\
\hline
\end{tabular}

(Akbar dan Hadi, 2010)

\section{Hasil dan Pembahasan}

Penelitian pengembangan yang telah dilakukan menghasilkan suatu produk ELKPD Berbasis Discovery Learning Menggunakan Aplikasi Adobe Acrobat XI Pro Extended Kesetimbangan Ion dan pH Larutan Garam untuk kelas XI SMA/MA. E-LKPD yang telah dikembangkan ini dapat digunakan saat proses pembelajaran di dalam kelas maupun sebagai bahan ajar mandiri saat berada di luar jam sekolah. Pemaparan hasill dan pembahasan dari setiap fase pengembangan Plomp yang telah dilakukan, diuraikan sebagai berikut :

\section{Fase Investigasi Awal}

- Analisis Ujung Depan

Analisis ujung depan telah dilakukan melalui wawancara dengan guru kimia MAN 3 Pekanbaru dan SMAN 4 Pekanbaru. Adapun informasi yang diperoleh bahwa guru sudah menggunakan bahan ajar cetak yang berupa buku teks, LKPD, dan fotocopy soal serta bahan ajar digital yang berupa power point teks (PPT) sehingga peserta didik kurang tertarik dalam pembelajaran. Namun selama masa pandemic covid-19 ini guru tidak menggunakan bahan ajar seperti LKPD karena 
kurang efektif. LKPD yang digunakan juga tidak dapat membuat peserta didik terlibat akif, dan menemukan konsep sendiri.

- Analisis Peserta Didik

Analisis peserta didik bertujuan untuk menganalisis karakteristik seperti perkembangan kognitif dan kemampuan dasar kimia. Peserta didik yang mempelajari materi kestimbangan ion dan $\mathrm{pH}$ larutan garam pada umumnya berusia 15-17 tahun tahun dan berdasarkan teori perkembangan kognitif Piaget, dalam usia tersebut peserta didik berada pada fase efisiensi intelektual maksimal, tetapi kurangnya pengalaman mengakibatkan pengetahuan peserta didik terbatas sehingga peserta didik kurang mampu memahami konsep pembelajaran yang bersifat abstrak.

- Analisis Kompetensi

Analisis kompetensi yang dilakukan yaitu mengacu pada kompetensi pengetahuan seperti kompetensi inti, kompetensi dasar pada materi asam dan basa. Hasil analisis kompetensi pada materi kestimbangan ion dan $\mathrm{pH}$ larutan garam (KD 3.11, dan 4.11) yang akan diajarkan dan disusun secara sistematis dalam bentuk peta konsep.

- Analisis Materi

Kemudian dilakukan analisis materi melalui telaah konsep-konsep materi kesetimbangan ion dan $\mathrm{pH}$ larutan garam yang kemudian disusun secara sistematis dan dirincikan berdasarkan kompetensi dasar, indikator pencapaian kompetensi dan tujuan pembelajaran.

\section{Fase Desain}

Fase desain bertujuan untuk merancang E-LKPD beserta instrumeninstrumen penelitian yang dibutuhkan berdasarkan hasil dari fase investigasi awal. Fase desain terdiri dari 2 tahap, yaitu tahap rancangan prototipe (produk) dan rancangan instrumen penilaian. Rancangan awal prototipe terdiri dari: a) Judul atau Cover, b) Daftar Isi, c) Petunjuk Penggunaan Aplikasi, d) Petunjuk Penggunaan LKPD, e) Kompetensi Dasar, f) Indikator Pencapaian Kompetensi, g) Petunjuk Belajar, h) Kegiatan E-LKPD dengan tahap Discovery Learning, i) Kolom Penilaian, 
j) Soal latihan, dan k) Daftar pustaka. Sedangkan desain instrumen berupa lembar validasi ahli materi dan ahli media serta angket respon pengguna yaitu guru dan peserta didik.

\section{Fase Realisasi/ Konstruksi}

Dihasilkan prototipe dan instrumen sebagai realisasi dari desain yang telah dirancang. E-LKPD Berbasis Discovery Learning Menggunakan Aplikasi Adobe Acrobat 11 Pro Extended Kesetimbangan Ion dan pH Larutan Garam telah direka cipta menggunakan aplikasi Microsoft office publisher dan juga aplikasi Adobe Acrobat 11 Pro Extended untuk memuat komponen-komponen E-LKPD yang layak digunakan dalam proses pembelajaran. E-LKPD disusun menjadi empat pertemuan, yang disesuaikan dengan silabus pembelajaran.

Realisasi desain instrumen menghasilkan lembar validasi dan angket respon pengguna. Poin-poin penilaian dalam setiap instrumen validasi dilengkapi dengan rubrik penilaian yang digunakan untuk membantu validator dalam menilai kelayakan serta penggunaan E-LKPD dalam proses pembelajaran. Angket respon pengguna telah dikonstruksi sedemikian rupa dan sesuai dengan kebutuhan penelitian yang merujuk pada BNSP 2007 modifikasi.

\section{Fase Validasi, Uji Coba dan Revisi}

Validasi (evaluation) bertujuan untuk mengetahui kelayakan produk E-LKPD yang akan digunakan pada kegiatan pembelajaran di sekolah. Validasi produk dilakukan oleh tim validator yang terdiri dari 2 orang validator materi yaitu dosen pendidikan kimia FKIP Universitas Riau, dosen Universitas Muhammadiyah Riau dan 2 orang validator media yaitu dosen jurusan teknik Informatika Universitas Islam Negeri Sultan Syarif Kasim Riau.

Validasi pada penelitian ini dilakukan sebanyak dua kali oleh masing-masing validator. Pada validasi I masih terdapat banyak saran dan komentar yang diberikan oleh validator untuk memperbaiki E-LKPD menjadi lebih baik.

Adapun hasil analisis oleh validator ahli materi berdasarkan aspek kelayakan isi, karakteristik Discovery Learning, aspek penyajian, aspek kebahasaan, dan aspek kegrafisan. Berikut tabel persentase skor validasi dari setiap aspek oleh tim validator materi disajikan pada Tabel 5. 
Tabel 5. Persentase Skor Oleh Validator Ahli Materi

\begin{tabular}{cccc}
\hline No & Aspek Penilaian & Persentase (\%) & Kategori \\
\hline 1 & Kelayakan Isi & $94,44 \%$ & Valid \\
\hline 2 & Karakteristik Discovery & $95,83 \%$ & Valid \\
\hline 3 & Learning & $90 \%$ & Valid \\
\hline 4 & Kelayakan Kebahasaan & $90,62 \%$ & Valid \\
\hline 5 & Kelayakanan Kenyajian & $93,75 \%$ & Valid \\
\hline \multicolumn{2}{c}{ Persentase Rata-Rata Skor } & $\mathbf{9 2 , 9 3 \%}$ & Valid \\
\hline
\end{tabular}

Aspek karakteristik Discovery Learning memperoleh nilai tertinggi dengan persentase 95,83\% yang menandakan bahwa tahapan-tahapn model Discovery Learning pada E-LKPD sudah jelas, hal ini menunjukkan bahwa E-LKPD yang dikembangkan dapat menuntut peserta didik untuk mengerjakan kegiatan sesuai dengan sintaks model yang digunakan.

Aspek kelayakan isi memperoleh persentase $94,44 \%$, dengan kriteria valid, artinya E-LKPD sudah sesuai dengan KD dan IPK dan sudah memenuhi substansi pokok bahasan kesetimbangan ion dan $\mathrm{pH}$ larutan garam. Selanjutnya, pada aspek kelayakan kegrafisan meperoleh persentase 93,75\%, artinya E-LKPD yang dikembangkan sudah memiliki desain tampilan yang menarik dan ilustrasi/gambar yang berhubungan dengan konsep pembelajaran.

Aspek kelayakan penyajian memperoleh persentase $90,62 \%$, artinya kelengkapatn format E-LKPD sudah sesuai dan E-LKPD sudah memberikan ruang yang cukup. Pernyataan ini didukung oleh (Depdiknas, 2008) yang menyatakan bahwa LKPD yang baik hendaknya memenuhi syarat konstruksi yaitu menyediakan ruang yang cukup untuk memberi keluasaan pada peserta didik untuk menulis, menggambar hal-hal yang ingin disampaikan oleh peserta didik. Selanjutnya, aspek kebahasaan memperoleh persentase $90 \%$, artinya bahasa yang digunakan sudah efektif dan efesien, istilah sudah konsisten, penggunaan tanda baca sudah 
disesuaikan dan penggunaan kaidah bahasa Indonesia sudah baik dan benar sehingga dapat memudahkan peserta didik untuk memahami informasi yang disajikan.

Hasil analisis oleh validator ahli media berdasarkan aspek ukuran E-LKPD, desain sampul E-LKPD, dan desain isi E-LKPD. Berikut tabel persentase skor validasi dari berbagai aspek oleh tim validator media disajikan pada Tabel 6 .

Tabel 6. Persentase Skor Oleh Validator Ahli Media

\begin{tabular}{cccc}
\hline NO & Aspek Penilaian & Persentase (\%) & Kriteria \\
\hline 1 & Ukuran E-LKPD & $100 \%$ & Valid \\
\hline 2 & Desain sampul E-LKPD (Cover) & $90,63 \%$ & Valid \\
\hline 3 & Desain isi E-LKPD & $94,32 \%$ & Valid \\
\hline & Persentase Rata-rata Skor & $\mathbf{9 4 , 9 8 \%}$ & Valid \\
\hline
\end{tabular}

Aspek ukuran E-LKPD memperoleh persentase tertinggi yaitu 100\% yang menunjukkan bahwa ukuran E-LKPD sudah sesuai dengan standar ISO dan materi isi E-LKPD. Aspek desain isi E-LKPD memperoleh 94,32\%, artinya E-LKPD sudah praktis dan bisa digunakan dalam proses pembelajaran dan tombol navigasi yang digunakan dalam E-LKPD dan sumber pada setiap gambar dan video sudah sesuai. Selanjutnya, aspek desain sampul E-LKPD (cover) memperoleh persentase 90,63\% dengan kategori valid, artinya ilustrasi pada sampul E-LKPD sudah sesuaii, warna dan unsur tata letak harmonis dan dapat memperjelas fungsi.

Beirkut desain produk E-LKPD berbasis Discovery Learning menggunakan aplikasi Adobe Acrobat 11 Pro Extended sebelum dan sesudah dilakukan validasi : 


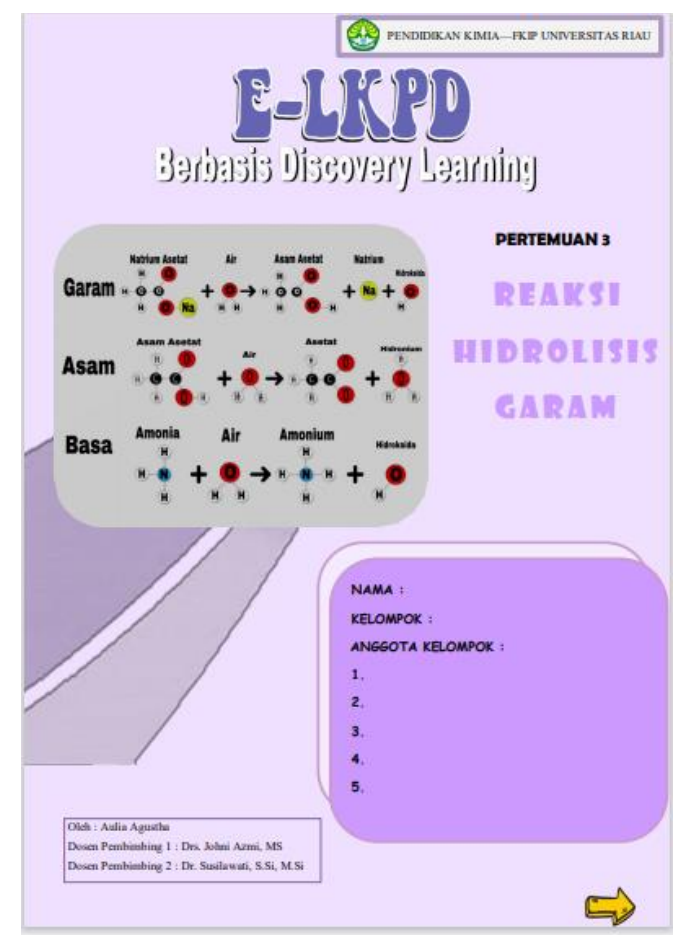

(a) Sebelum Validasi

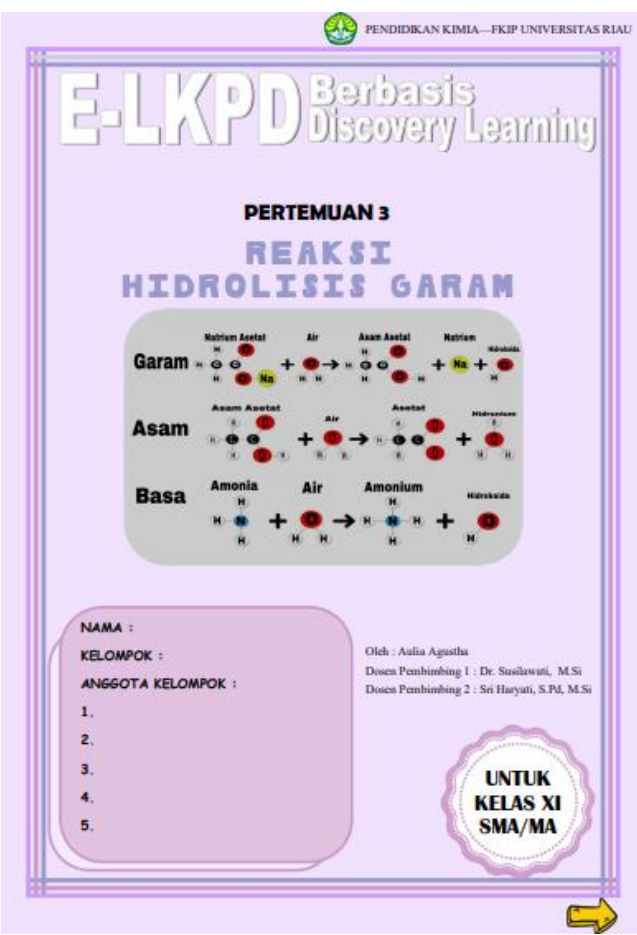

(b) Sesudah Validasi

\section{Gambar 2. Tampilan E-LKPD Sebelum dan Sesudah Validasi}

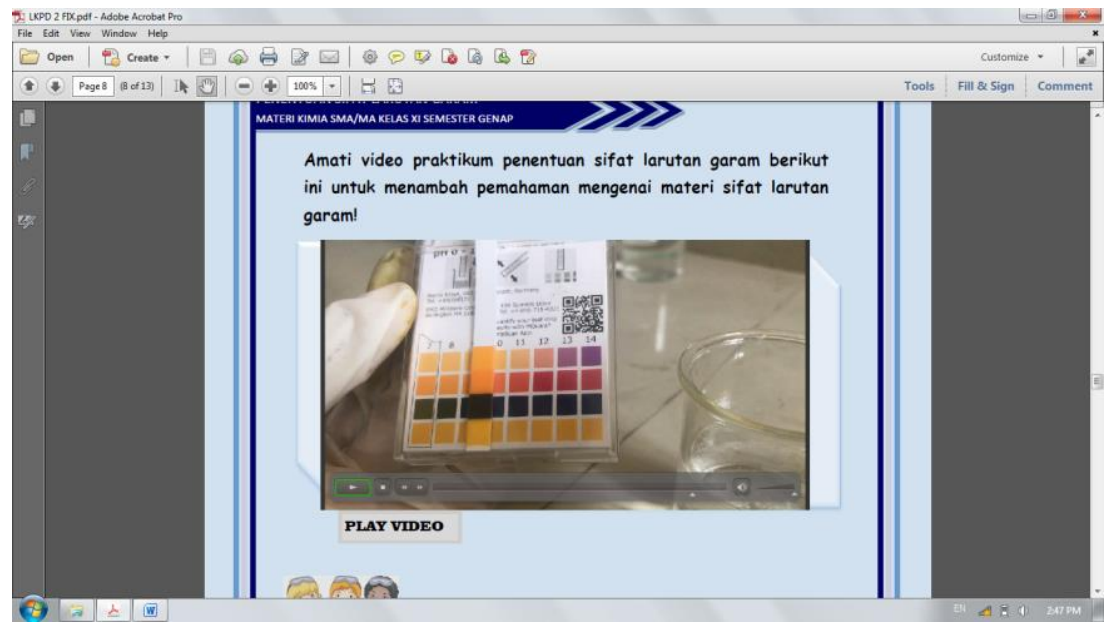

\section{Gambar 3. Tampilan Penyajian Video E-LKPD pada Aplikasi} Adobe Acrobat 11 Pro Extended

Setelah E-LKPD selesai divalidasi oleh tim validator ahli materi dan ahli media dan direvisi oleh peneliti, maka dilakukan uji satu-satu kepada 3 orang peserta didik yang sudah mempelajari materi kesetimbangan ion dan $\mathrm{pH}$ larutan garam dengan 
tingkat kemampuan yang berbeda untuk mengerjakan E-LKPD yang telah dinyatakan valid oleh validator. Pada saat pengerjaan E-LKPD peserta didik masih ada yang bertanya mengenai cara memutarkan video pembelajaran dan peneliti menjelaskan kembali sehingga peserta didik mulai mengerti cara penggunaannya. Setelah selesai mengerjakan E-LKPD, peserta didik memberi saran yaitu pada ELKPD 1 tabel jawaban di tahap problem statement supaya size diperbesar dan pada E-LKPD 2 di tahap data processing tabel jawaban soal nomor 3 dibesarkan lagi. Untuk E-LKPD perhitungan lebih baik disiapkan dahulu rumus-rumus yang berkaitan dengan materi agar tidak terlalu lama mencari di internet. Komentarnya yaitu video praktikum yang disajikan dalam E-LKPD menarik dan mudah dipahami. Komentar dan saran yang diberikan diperbaiki.

Selanjutnya meminta respon kepada 3 orang guru kimia dan 20 orang peserta didik dari MAN 3 Pekanbaru dan SMAN 4 Pekanbaru yang sudah mempelajari materi kesetimbangan ion dan $\mathrm{pH}$ larutan garam terhadap E-LKPD yang telah dikembangkan. Berikut disajikan ke dalam tabel hasil yang diperoleh dari masing-masing respon pengguna yaitu :

Tabel 7. Hasil Persentase Respon Pengguna

\begin{tabular}{ccc}
\hline Responden & Hasil (\%) & Kategori \\
\hline Guru & $94,44 \%$ & Sangat Baik \\
\hline Peserta Didik & $90,75 \%$ & Menarik \\
\hline Rata-rata & $\mathbf{9 1 , 9 7 \%}$ & $\begin{array}{c}\text { Sangat Baik } \\
\text { dan Menarik }\end{array}$ \\
\hline
\end{tabular}

Berdasarkan respon tersebut maka diperoleh E-LKPD berbasis Discovery Learning menggunakan aplikasi Adobe Acrobat 11 Pro Extended pada materi Kesetimbangan ion dan $\mathrm{pH}$ larutan garam yang final. Hal ini didukung oleh hasil penelitian Liza Septia Ahmad (2020) dengan judul pengembangan LKPD fisika berbasis etnosains menggunakan model Discovery Learning memperoleh skor rata-rata $88,4 \%$ kategori sangat baik terhadap kelayakan LKPD model Discovery Learning. 
Penelitian selanjutnya didukung oleh Candra Apriyanto (2019) dengan judul pengembangan E-LKPD berpendekatan Saintifk kesimpulan terhadap produk E-LKPD ini menurut tanggapan para guru sangat baik dengan persentase skor $86 \%$, dan hasil uji coba kelompok kecil kepada 10 orang siswa kelas XII MIPA SMAN 7 Jambi menunjukkan respon sangat baik dengan persentase respon siswa sebesar $92,2 \%$.

\section{Kesimpulan}

E-LKPD berbasis Discovery Learning menggunakan aplikasi Adobe Acrobat 11 Pro Extended pada materi kesetimbangan ion dan $\mathrm{pH}$ larutan garam yang telah dikembangkan dinyatakan valid menurut validator materi berdasarkan aspek kelayakan isi, karakteristik Discovery Learning, kebahasaan, penyajian, dan kegrafisan diperoleh kategori valid dengan nilai (>90\%), dan valid menurut validator media berdasarkan aspek ukuran E-LKPD, desain sampul, dan desain isi E-LKPD diperoleh kategori valid dengan nilai $(>90 \%)$. Respon pengguna oleh 3 orang guru kimia diperoleh kategori sangat baik dengan nilai $(>90 \%)$ dan praktis. Serta respon 20 orang peserta didik diperoleh kategori menarik dengan nilai $(>80 \%)$.

Penelitian pengembangan E-LKPD berbasis Discovery Learning menggunakan aplikasi Adobe Acrobat 11 Pro Extended pada materi kesetimbangan ion dan $\mathrm{pH}$ larutan garam dilanjutkan dengan implementasi sehingga dapat dimanfaatkan oleh peserta didik dan guru untuk menguji keefektifan dalam proses pembelajaran, serta dapat digunakan sebagai acuan dalam menyusun E-LKPD pada materi kimia lainnya.

\section{Daftar Referensi}

Akbar Sa'dun, Hadi Sriwijaya. 2010. Pengembangan Kurikulum dan Pembelajaran IImu Pengetahun Sosial (IPS). Cipta Media. Yogyakarta

Candra Apriyanto, Yusnelti, Asrial. 2019. Pengembangan E-LKPD Berpendekatan Saintifik Larutan Elektrolit dan Non Elektrolit. Journal of The Indonesian Society of Integerates Chemistry, 11(1), 38-42. Universitas Jambi.

Depdiknas. 2008. Permendikbud no 65/3013: Standar Proses Pendidikan Dasar dan Menengah. BSNP. Jakarta 
Efisitek. 2007. Adobe Acrobat Professional 8. Yrama Widya. Bandung

Ervin Azhar. 2011. Pengembangan Perangkat Pembelajaran Teori Peluang Berbasis RME untuk Meningkatkan Pemahaman, Penalaran, dan Komunikasi Matematik Peserta Didik SLTA. Prosiding 213-222. 3 Desember 2011. UPI. Bandung

Fitri Apriani Pratiwi. 2014. Pengaruh Penggunaan Model Discovery Learning dengan Pendekatan Saintifik terhadap Keterampilan Berpikir Kritis Siswa SMA. Jurnal Pendidikan dan Pembelajaran volume 3 No. 7. Universitas Tanjupura,Pontianak.

Liza Septia Ahmad. 2020. Pengembangan Lembar Kerja Peserta Didik (LKPD) Fisika Berbasis Etnosains Menggunakan Model Discovery Learning Untuk Meningkatkan Keterampilan Berpikir Kritis Siswa SMA. Jurnal Kumparan Fisika, 3(2), 121-130. Universitas Bengkulu.

M. Thobroni. 2015. Belajar dan Pembelajaran : Teori dan Praktek. Arr-Ruzz Media Yogyakarta.

Riduwan. 2012. Skala Pengukuran Variabel-variabel Penelitian. Alfabeta. Bandung Sugiyono. 2017. Metode Penelitian dan Pengembangan (Research and Developmen/ $R \& D)$. Alfabeta. Bandung.

Tika Eka Ningrum. 2018. Buku Sekolah Elektronik Berbasis Multimedia Sebagai Sumber Belajar Untuk SMK Kompetensi Keahlian Teknik Computer Jaringan Kelas X. Skripsi. UNY. Yogyakarta

Trilling and Fadel. 2009. $21^{\text {st }}$ Century Skills : Learning Life in Our Times. Jossey Bass. USA

Valentina Nunung Dea Ristanti, Mumun Nurmilawati, Tutut Indah Sulistiyowati. 2019. Respon Siswa Terhadap Modul Pembelajaran Berbasis SAVI (Somatic, Auditory, Visualitation, Intellegency) Pada Materi Ekosistem di SMAN 1 Papar. Jurnal Biologi dan Pembelajarannya 6(1): 36-38 